Research Article

\title{
Knowledge, attitude, and practice of pharmacovigilance among health care professionals in a tertiary care hospital: a cross sectional study
}

\author{
Vinoth Kalaichelvan*, Meenakshi Balasubramanian, Ezhil J. Ramya
}

\begin{abstract}
Department of Pharmacology, Tirunelveli Medical College, Tirunelveli, Tamilnadu, India

Received: 25 July 2016

Accepted: 28 August 2016

*Correspondence to:

Dr. Vinoth Kalaichelvan,

Email: vinwiz2000@gmail.com
\end{abstract}

Copyright: (C) the author(s), publisher and licensee Medip Academy. This is an openaccess article distributed under the terms of the Creative Commons Attribution NonCommercial License, which permits unrestricted noncommercial use, distribution, and reproduction in any medium, provided the original work is properly cited.

\begin{abstract}
Background: Spontaneous reporting of Adverse drug reactions (ADRs) has played an important role in the detection of serious, unsuspected, and unusual ADRs previously not detected during the clinical trials. However, underreporting remains a major obstacle in the implementation of pharmacovigilance program. The present cross-sectional study was conducted to assess the knowledge, attitude, and practice (KAP) related to pharmacovigilance among the health-care professionals (HCPs) in Tirunelveli Medical College Hospital, Tamilnadu.

Methods: To assess KAPs of Health care professionals toward pharmacovigilance and ADR reporting; a predesigned, structured, 12 item questionnaire was used.

Results: A total of 200 questionnaires were distributed among the HCPs including Postgraduate, Interns and Staff nurses. $72.7 \%$ postgraduates, $54.29 \%$ interns and $52.63 \%$ of staff nurses were aware regarding the existence of a National Pharmacovigilance Program of India. $72.7 \%$ postgraduates, $65.71 \%$ interns and $52.63 \%$ staff nurses felt that ADR reporting is a professional obligation for them .Only $37.14 \%$ interns, $15.79 \%$ staff nurses and $11.4 \%$ postgraduates have been trained for reporting adverse reactions. Although all staff nurses $(100 \%)$ followed by $79.50 \%$ postgraduates and $48.57 \%$ interns experienced ADR in their practice, only $31.58 \%$ staff nurses, $20.50 \%$ postgraduates and $11.43 \%$ interns have ever reported ADR to pharmacovigilance centre.

Conclusions: The deficiencies in knowledge and attitude require urgent attention not only to improve the rate of spontaneous reporting, but also for enhanced safety of the patients. Pharmacovigilance should be included in the nursing curriculum and workshops should be conducted for the undergraduate and postgraduate medical students regularly.
\end{abstract}

Keywords: ADR reporting, Health-care professionals, Pharmacovigilance

\section{INTRODUCTION}

Pharmacovigilance is the science and activities related to the detection, assessment, understanding, and prevention of adverse effects or any other possible drug related problems. ${ }^{1}$ WHO Collaborating centre for international drug monitoring is located at Uppsala, Sweden. WHO Global individual case safety report database called Vigibase receives reports of adverse reactions from all its member countries including India. The Central Drugs Standard Control Organisation (CDSCO), New Delhi has initiated a nation-wide pharmacovigilance programme with the Indian Pharmacopoeia Commission (IPC), Ghaziabad, Uttar Pradesh as the National Coordinating Centre (NCC) for monitoring adverse drug reactions (ADR) in the country to safe-guard Public Health. NCCPvPI monitors the ADRs among Indian population and helps the regulatory authority of India in taking CDSCO decision for safe use of medicines. ${ }^{2}$ To transform the concept of pharmacovigilance into practice for enhancing the safety of patients, ADR monitoring centres (AMCs) are being set up across the country under Pharmacovigilance Programme of India (PvPI). Our Institute, Tirunelveli Medical College is an ADR 
monitoring center. Spontaneous reporting of ADRs has played a major role in the detection of unsuspected, serious, and unusual ADRs previously undetected during the clinical trial phases. However, underreporting still remains a major obstacle in the complete success of pharmacovigilance program. ${ }^{3}$ It is found that only $6-10 \%$ of all ADRs are reported. ${ }^{45}$ This high rate of underreporting is a matter of great concern which can delay the detection of serious ADRs and consequently have a major negative impact on the public health.

There is a requirement for constant training and enactment of regulations for ADR reporting among Health Care Professionals (HCPs). Previously reported study has found that underreporting of ADR is related with shortcomings in the knowledge and attitude among health-care professionals. ${ }^{6,7}$ It is important for health-care professionals to know how to report, when to report and where to report an ADR. The active participation of health-care professionals in the pharmacovigilance program can improve the ADR reporting. ${ }^{8}$ The present study was done to assess the knowledge, attitude, and practices (KAPs) of the Health care professionals working in Tirunelveli medical college hospital and to find out the reasons for under reporting of ADR in our AMC.

\section{METHODS}

The Study was commenced in Tirunelveli medical college hospital after getting approval from the Institutional Ethical Committee. This is a questionnaire based cross sectional study where a predesigned questionnaire consisting of 20 questions was used to assess the knowledge, attitude and practice of pharmacovigilance among the HCPs. Candidates who have passed the final MBBS exams and are doing internship (group 1) in Tirunelveli Medical College Hospital, Postgraduate medical students of clinical departments (group 2) in Tirunelveli Medical College, Staff nurses (group 3) working in Tirunelveli Medical College Hospital. The participants included in the study were 100 interns, 50 post graduates, and 50 Staff nurses. Candidates who were not willing to participate were excluded from the study. An informed consent was taken from all the participants before enrolling them in the study. The questionnaires were distributed to all the three groups. The participants were asked to choose an appropriate response from the provided list of options. The questionnaires were collected after 30 minutes. The completed response sheets were carefully assessed by the investigator.

After collecting the completely filled up questionnaire from the participants, the investigator explained about pharmacovigilance and its importance to the study participants. Response sheets were analysed questionwise and their percentage value were calculated. Data were analysed using descriptive statistics with Microsoft excel for windows 10 .

\section{RESULTS}

The term pharmacovigilance was better known to interns $(60 \%)$ than postgraduates $(40.9 \%)$ and staff nurses $(5.26 \%)$. There is a very little difference among the three groups of HCPs regarding the knowledge about the purpose of pharmacovigilance. Postgraduates (72.9\%) know better about the existence of PvPI than interns $(54.29 \%)$ and staff nurses $(52.63 \%)$. Staff nurses $(84.21 \%)$ know better about the presence of AMC in our institute than the other two groups. Post graduates $(81.80 \%)$ correctly identified the professionals responsible for ADR reporting than the other two groups (Table 1).

\section{Table 1: Knowledge of pharmacovigilance among HCPs.}

\begin{tabular}{|llll|}
\hline \hline $\begin{array}{l}\text { Knowledge } \\
\text { related questions }\end{array}$ & $\begin{array}{l}\text { Staff } \\
\text { nurses } \\
\text { Correct } \\
\text { response }\end{array}$ & $\begin{array}{l}\text { Interns } \\
\text { Correct } \\
\text { response }\end{array}$ & $\begin{array}{l}\text { Postgraduates } \\
\text { Correct } \\
\text { response }\end{array}$ \\
\hline $\begin{array}{l}\text { What is } \\
\text { pharmacovigilance? }\end{array}$ & $5.26 \%$ & $60 \%$ & $40.9 \%$ \\
\hline $\begin{array}{l}\text { Purpose of } \\
\text { pharmacovigilance }\end{array}$ & $42.73 \%$ & $45.71 \%$ & $50 \%$ \\
\hline Existence of PvPI & $52.63 \%$ & $54.29 \%$ & $72.7 \%$ \\
\hline $\begin{array}{l}\text { AMC in } \\
\text { Tirunelveli } \\
\text { Medical College }\end{array}$ & $84.21 \%$ & $25.71 \%$ & $31.80 \%$ \\
\hline $\begin{array}{l}\text { Professionals } \\
\text { responsible for } \\
\text { ADR reporting }\end{array}$ & $42.11 \%$ & $54.28 \%$ & $81.80 \%$ \\
\hline
\end{tabular}

The fact that reporting of ADR is a professional obligation was better known by postgraduates $(72.70 \%)$ than interns $(65.71 \%)$ followed by staff nurses $(52.63 \%)$. All the postgraduates $(100 \%)$ felt that ADR reporting is necessary followed by staff nurses $(94.73 \%)$ and interns (94.28\%).All the staff nurses (100\%) felt that pharmacovigilance should be taught in detail to HCPs followed by postgraduates $(93.20 \%)$ and interns $(85.71 \%)$ (Table 2).

Table 2: Attitude of the HCPs regarding pharmacovigilance.

\begin{tabular}{|c|c|c|c|}
\hline $\begin{array}{l}\text { Attitude related } \\
\text { questions }\end{array}$ & $\begin{array}{l}\text { Staff } \\
\text { nurses }\end{array}$ & Interns & Postgraduates \\
\hline & Yes & Yes & Yes \\
\hline $\begin{array}{l}\text { ADR reporting is } \\
\text { professional } \\
\text { obligation }\end{array}$ & $52.63 \%$ & $65.71 \%$ & $72.70 \%$ \\
\hline $\begin{array}{l}\text { ADR reporting is } \\
\text { necessary }\end{array}$ & $94.73 \%$ & $94.28 \%$ & $100 \%$ \\
\hline $\begin{array}{l}\text { Pharmacovigilance } \\
\text { should be taught in } \\
\text { detail to HCPs }\end{array}$ & $100 \%$ & $85.71 \%$ & $93.2 \%$ \\
\hline
\end{tabular}


The staff nurses had seen more number of ADRs (100\%) than the other two groups - postgraduates $(79.50 \%)$ and interns $(48.57 \%)$. Staff nurses had seen the ADR forms more $(68.42 \%)$ than the interns $(40 \%)$ and postgraduates $(31.80 \%)$. The interns $(37.14 \%)$ had received better training to report an ADR than other HCPs. But still in all the groups of HCPs, the reporting of ADR to the AMC is low. Only $31.58 \%$ of staff nurses report ADR to the AMC followed by postgraduates $(20.50 \%)$ and interns $(11.43 \%)$ (Table 3).

Table 3: Pharmacovigilance related practice of the HCPs.

\begin{tabular}{|llll|}
\hline $\begin{array}{l}\text { Practice } \\
\text { related } \\
\text { questions }\end{array}$ & $\begin{array}{l}\text { Staff } \\
\text { nurses }\end{array}$ & $\begin{array}{l}\text { Ynterns } \\
\text { Yes }\end{array}$ & Yostgraduates \\
\hline $\begin{array}{l}\text { Experienced } \\
\text { ADR in } \\
\text { practice }\end{array}$ & $100 \%$ & $48.57 \%$ & $79.50 \%$ \\
\hline $\begin{array}{l}\text { Ever seen the } \\
\text { ADR reporting } \\
\text { form }\end{array}$ & $68.42 \%$ & $40 \%$ & $31.80 \%$ \\
\hline $\begin{array}{l}\text { Trained to } \\
\text { report ADR }\end{array}$ & $15.79 \%$ & $37.14 \%$ & $11.4 \%$ \\
\hline $\begin{array}{l}\text { Ever reported } \\
\text { ADR to the }\end{array}$ & $31.58 \%$ & $11.43 \%$ & $20.50 \%$ \\
AMC & & & \\
\hline
\end{tabular}

Lack of time is the major discouraging factor for staff nurses and interns. Difficulty in deciding whether the occurred reaction is drug related is the major discouraging factor for the postgraduates (Figure 1).

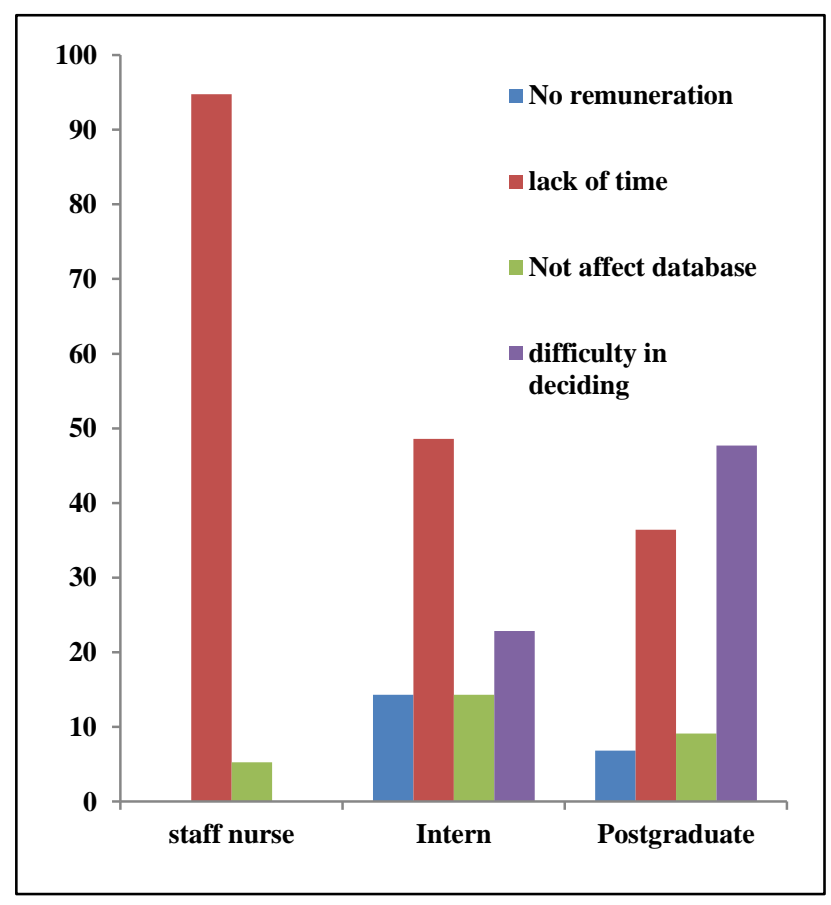

Figure 1: Reasons for not reporting ADR.

\section{DISCUSSION}

The present study was taken up to assess the knowledge, attitude and practice of pharmacovigilance among health care professionals and to find out the reasons for under reporting.

\section{Knowledge of pharmacovigilance}

The interns followed by postgraduates know better about the term pharmacovigilance than the staff nurses. This is because lecture classes on Pharmacovigilance are being taken for the undergraduate students for the past five years in our Institute. There is very little difference among the three groups of HCPs regarding the knowledge about the purpose of pharmacovigilance. Postgraduates know better about the existence of PvPI and correctly identified the professionals responsible for ADR reporting than the other two groups. Staff nurses know better about the presence of AMC in our institute than the other two groups because ADR reporting forms are distributed to the wards by the AMC for the past two years.

\section{Attitude regarding pharmacovigilance}

All the three groups of HCPs felt that ADR reporting is necessary and pharmacovigilance should be taught in detail to HCPs. The fact that reporting of $\mathrm{ADR}$ is a professional obligation was better known by the postgraduates than the other groups.

\section{Practice of pharmacovigilance}

The staff nurses had seen more number of ADRs than the other two groups of HCPs. This is probably due to their long years of medical service and experience compared to other two groups of HCPs. Staff nurses had seen the ADR forms more than the interns and postgraduates. The interns had received better training to report an ADR than other HCPs. This might be due to pharmacovigilance training they received during their undergraduate years. But still in all the groups of HCPs, the reporting of ADR to the AMC is low.

\section{Reasons for not reporting ADR}

Lack of time is the major discouraging factor for staff nurses and interns. Difficulty in deciding whether the occurred reaction is drug related is the major discouraging factor for the postgraduates. Similar reasons were cited in a study done by Torwane et al. ${ }^{12}$ HCPs cannot expect remuneration for ADR reporting since it is part of their professional obligation. Not reporting a single case would not affect the database is a wrong notion. One such proven example is that piperacillin/tazobactam, a commonly used antibiotic was reported to cause severe hypokalemia even in patients with normal renal and hepatic functions. This was found out by the reporting of 13 individual case study reports (ICSRs) to NCC-PvPI. Now it is recommended to periodically assess serum 
electrolyte. ${ }^{13}$ Each and every case of ADR is important so that the accuracy of the ADR Database will increase. HCPs must attend more training programs on pharmacovigilance so that the difficulty they experience in deciding ADR will be reduced in future. The problem of lack of time will not be solved unless the HCPs allot a specific time slot to report ADR daily.

There is a huge gap between the ADR experienced and ADR reported by healthcare professional. According to the study done by Tabali $\mathrm{M}$ et al, educational intervention has been found to improve spontaneous reporting of ADRs. ${ }^{14}$ Therefore, there is a need to conduct training program to all the HCPs for improving spontaneous reporting of ADRs. Regular Continuous Medical Education (CMEs) and refresher courses will be useful.

\section{CONCLUSION}

There should be regular clinical society meeting on ADRs. Pharmacovigilance should be included in the curriculum for nursing students. Pharmacovigilance workshops should be conducted for the undergraduate and postgraduate medical students regularly apart from the induction of pharmacovigilance classes for the undergraduate medical students.

Funding: No funding sources

Conflict of interest: None declared

Ethical approval: The study was approved by the Institutional Ethics Committee

\section{REFERENCES}

1. World Health Organization Collaborating Centre for International Drug Monitoring. The importance of pharmacovigilance. Safety monitoring of medicinal products. Geneva: World Health Organization; 2002. Available at http://apps.who.int/medicinedocs/en/d/Js4893e/.

Accessed on 8 October 2015.

2. Pharmacovigilance programme of India 2010. CDSCO, Ministry of Health and Family Welfare, Government of India. 2010. Available at http://cdsco.nic.in/ pharmacovigilance.htm. Accessed on 8 October 2015.

3. Lopez Gonzalez E, Herdeiro MT, Figueiras A. Determinants of under reporting of adverse drug reactions: a systematic review. Drug Saf. 2009;32:19-31.

4. Smith CC, Bennett PM, Pearce HM, Harrison PI, Reynolds DJ, Aronson JK, et al. Adverse drug reaction in a hospital general medical unit meriting notification to the committee on safety of medicines. Br J Clin Pharmacol. 1996;42:423-42.

5. Feely J, Moriarty S, O'Connor P. Stimulating reporting of adverse drug reaction by using a fee. $\mathrm{Br}$ Med J. 1990;300:22-3.

6. Khan SA, Goyal C, Chandel N, Rafi M. Knowledge, attitudes, and practice of doctors to adverse drug reaction reporting in a teaching hospital in India: An observational study. J Nat Sci Biol Med. 2013;4:1916.

7. Muraraiah S, Rajarathna K, Sreedhar D, Basavalingu D, Jayanthi CR. A questionnaire study to assess the knowledge, attitude and practice of pharmacovigilance in a paediatric tertiary care centre. J Chem Pharm Res. 2011;3:416-22.

8. Remesh A. Identifying the reasons for under reporting of ADR: across sectional survey. Res J Pharm Biol Chem Sci. 2012;3:1379-86.

9. Li Q, Zhang SM, Chen HT, Fang SP, Yu X, Liu D, et al. Awareness and attitudes of healthcare professionals in Wuhan, China to the reporting of adverse drug reactions. Chin Med J. 2004;117:856-61.

10. McGettigan P, Feely J. ADR reporting: opinion and attitudes of medical practitioners in Ireland. Pharmacoepidemiol Drug Saf. 1995;4:355-8.

11. Pirmohamed M, James S, Meakin S, Green C, Scott $\mathrm{AK}$, Walley $\mathrm{TJ}$, et al. Adverse drug reactions as cause of admission to hospital: prospective analysis of 18820 patients. Br Med J. 2004;329:15-9.

12. Torwane NA, Hongal S, Gouraha A, Saxena E, Chavan K. Awareness related to reporting of adverse drug reactions among health caregivers: a crosssectional questionnaire survey. J Nat Accred Board Hosp Healthcare Providers. 2015;2:23-9.

13. Drug safety information. PvPI. 2015;5:9-10.

14. Tabali M, Jeschke E, Bockelbrink A, Witt CM, Willich SN, OstermannT, et al. Educational intervention to improve physician reporting of adverse drug reactions (ADRs) in a primary care setting in complementary and alternative medicine. BMC Public Health. 2009;9:274.

Cite this article as: Vinoth K , Meenakshi B, Ezhil Ramya J. Knowledge, attitude, and practice of pharmacovigilance among health care professionals in a tertiary care hospital: a cross sectional study. Int J Basic Clin Pharmacol 2016;5:2190-3. 